Meta

Journal des traducteurs

Translators' Journal

\title{
Bilingualism and Literary (Non-)Translation: The Case of Trieste and Its Hinterland
}

\section{Martina Ožbot}

Volume 59, numéro 3, décembre 2014

Traduction et plurilinguisme officiel

Translation and Official Multilingualism

URI : https://id.erudit.org/iderudit/1028663ar

DOI : https://doi.org/10.7202/1028663ar

Aller au sommaire du numéro

Éditeur(s)

Les Presses de l’Université de Montréal

ISSN

0026-0452 (imprimé)

1492-1421 (numérique)

Découvrir la revue

Citer cet article

Ožbot, M. (2014). Bilingualism and Literary (Non-)Translation: The Case of Trieste and Its Hinterland. Meta, 59(3), 673-690.

https://doi.org/10.7202/1028663ar

\section{Résumé de l'article}

La présente contribution traite de la faible activité de traduction caractéristique des environnements bilingues. L'analyse porte sur la situation dans la ville de Trieste et ses environs où une minorité slovène substantielle vit depuis des siècles parallèlement à la population romane, principalement italianophone, comme le font divers autres groupes ethniques moins nombreux. Les communautés italienne et slovène ont connu des parcours historiques assez différents et ont été ponctuellement en conflit au sujet de questions d'ordre national, situation compliquée ensuite par les circonstances politiques. Dans une grande mesure, les deux groupes ethniques ont vécu côte à côte en ne portant qu'un intérêt minimal à la production culturelle de l'autre. Cela a également eu un impact sur la traduction littéraire. Jusqu'à une époque récente, les publications dans ce domaine sont restées peu nombreuses et la réception des oeuvres traduites encore plus modeste, et ce, en dépit de la riche littérature tant italienne que slovène provenant de Trieste. Cet article vise à identifier les principaux aspects de cette relation traductionnelle et à en discuter, en prenant en compte les facteurs sociaux, politiques, culturels, littéraires et linguistiques qui la sous-tendent. Il semble toutefois que la situation ait changé au début des années 1990, quand les asymétries entre les deux groupes ethniques ont commencé à diminuer et quand les culture et langue slovènes ont gagné du terrain en termes d'importance et de reconnaissance, ce qui a, entre autres, ouvert de nouvelles perspectives à la traduction littéraire.
Ce document est protégé par la loi sur le droit d'auteur. L'utilisation des services d'Érudit (y compris la reproduction) est assujettie à sa politique d'utilisation que vous pouvez consulter en ligne.

https://apropos.erudit.org/fr/usagers/politique-dutilisation/ 


\title{
Bilingualism and Literary (Non-)Translation: The Case of Trieste and Its Hinterland
}

\author{
MARTINA OŽBOT \\ University of Ljubljana, Ljubljana, Slovenia \\ martina.ozbot@guest.arnes.si
}

\section{RÉSUMÉ}

La présente contribution traite de la faible activité de traduction caractéristique des environnements bilingues. L'analyse porte sur la situation dans la ville de Trieste et ses environs où une minorité slovène substantielle vit depuis des siècles parallèlement à la population romane, principalement italianophone, comme le font divers autres groupes ethniques moins nombreux. Les communautés italienne et slovène ont connu des parcours historiques assez différents et ont été ponctuellement en conflit au sujet de questions d'ordre national, situation compliquée ensuite par les circonstances politiques. Dans une grande mesure, les deux groupes ethniques ont vécu côte à côte en ne portant qu'un intérêt minimal à la production culturelle de l'autre. Cela a également eu un impact sur la traduction littéraire. Jusqu'à une époque récente, les publications dans ce domaine sont restées peu nombreuses et la réception des œuvres traduites encore plus modeste, et ce, en dépit de la riche littérature tant italienne que slovène provenant de Trieste. Cet article vise à identifier les principaux aspects de cette relation traductionnelle et à en discuter, en prenant en compte les facteurs sociaux, politiques, culturels, littéraires et linguistiques qui la sous-tendent. Il semble toutefois que la situation ait changé au début des années 1990, quand les asymétries entre les deux groupes ethniques ont commencé à diminuer et quand les culture et langue slovènes ont gagné du terrain en termes d'importance et de reconnaissance, ce qui a, entre autres, ouvert de nouvelles perspectives à la traduction littéraire.

\section{ABSTRACT}

This article addresses the question of weak translation activity in bilingual settings. It presents an analysis of the situation in the city of Trieste and its surroundings, where a substantial Slovene minority has lived for centuries alongside the Romance-speaking (mainly Italian) population as well as various other smaller ethnic groups. The Italian and the Slovene communities have had different histories and at various points conflicts between them have arisen, sparked by national issues and complicated further by political circumstances. To a large extent, the two ethnic groups have lived parallel lives, often showing only minimal interest in each other's culture. This has had an impact on literary translation, the output of which has been rather modest until recently, and often even more so on the reception of translated works - in spite of the city's rich literature in both Italian and Slovene. This article seeks to identify and explore the nature of this translational relationship, taking into account the underlying social, political, cultural, literary, and linguistic factors. It argues that the situation began to change in the early 1990 s when the asymmetries between the two ethnic groups started to diminish and the Slovene culture and language gained greater recognition, which in turn opened new prospects for translation.

\section{MOTS-CLÉS/KEYWORDS}

traduction littéraire, bilinguisme, politique linguistique, politique de traduction, activité de traduction réduite, Trieste

literary translation, bilingualism, reduced translation activity, language policy, translation policy, Trieste 


\section{A preliminary remark}

In translation research, much attention has been devoted to trying to explain and understand the reasons which motivate the position translated texts come to occupy in a given target environment - in terms of their cultural impact, literary influence, and their function in the broadest sense. These are, of course, natural and legitimate questions which need to be dealt with if we are to arrive at an understanding of how translations are embedded in literary and, more generally, in textual systems and how they function in societies. However, apart from studying translations that actually exist and are in most cases available to the researcher, it is also important to reflect upon missing or reduced translation activity characteristic of various target cultural settings, including bilingual and multilingual ones. Poor or absent translation activity and the ensuing (relative) lack of translated texts call for analysis, which should ultimately shed light on the conditions for translation to take place, on the circumstances that encourage or hinder translation processes and on translation as an instrument of interliterary, as well as intercultural and interethnic relations (see Lane-Mercier 2011: 164). The aim of this paper is to examine a case of weak translation activity and reduced cultural exchange which have for a long time been typical of Italian and Slovene literature produced in the city of Trieste and its surroundings, although the situation has changed significantly in the past couple of decades. ${ }^{1}$

\section{Background considerations: multiculturalism in Trieste}

\subsection{Historical context}

Trieste, the northernmost port on the Adriatic, is one of the many historically multilingual and multicultural cities of Europe. What is particular about its linguistic and cultural makeup is that it is the meeting place of representatives of the three main European cultural groups: Romance, Slavic and - especially in the past - Germanic. This is not only a result of migration but follows naturally from the city's position in an area where the territories inhabited by Italians, Friulians, Slovenes, Croats, and Austrian Germans meet. The growth of Trieste as a multilingual and multicultural city was encouraged in particular after 1719 when the Holy Roman Emperor and Archduke of Austria Charles VI granted it the status of a free trade harbour (porto franco). As a consequence, people from various parts of the Empire and beyond began to flow into the place, which offered exceptional opportunities for commercial and economic development. Besides the peoples mentioned, in the city's heyday the Triestine ethnic mix also included Serbs, Hungarians, Greeks, Armenians, Jews, Britons, and others. This can still be noted in some of its architectural traits as well as in the lively co-existence of different religious communities still present in Trieste today. The largest urban ethnic group after the Italian is the Slovene group, who in the past (and to some extent also today) was especially concentrated in certain districts. In the second half of the nineteenth century and in the decades before the First World War, the Slovenes accounted for about a quarter of the residents with the number of Italians (and Friulians ${ }^{2}$ ) being more than twice as high. When a census was conducted in 1910, Trieste had about 230,000 inhabitants - around 140,000 of whom were Italians - and was the biggest Slovene town with about 60,000 Slovenes living there (Vivante 1912/1984: 172; Cattaruzza 1997: 208-214), while the total population of the main city 
in Slovenia and now the country's capital, Ljubljana, was less than that, at about 45,000, although ethnically much more homogeneous. ${ }^{3}$ The total number of people living in the Austro-Hungarian Empire was around 51 million, of which Slovenes made up 3\% (Wolf 2011: 111), a percentage higher than that of Italians.

Given the significant presence of Slovenes in the bustling emporium that was Trieste, it is not surprising that the place was perceived as a vital part of the Slovene national territory, its economic hub and an important centre of Slovene culture with a thriving publishing industry and a lively theatre scene. The cultural significance of the city, which was not only bigger but also more cosmopolitan than the Germandominated and more provincial Ljubljana, is illustrated by the fact that shortly before the First World War, a suggestion was put forward for the first Slovene university to be founded there (Tuma 1997: 295-299; see also Ara and Magris 1987: 70; Grdina 2003: $210-215){ }^{4}$ This did not happen since some years later, in 1919, a university was established in Ljubljana which, after the fall of the Austro-Hungarian Empire, became part of Yugoslavia. Trieste, on the other hand, was incorporated into Italy. This period brought an end to its special status in trading and tax policies, which meant that its period of greatness was over. In addition to economic decline, the city, like the region as a whole, began to face severe political problems associated with the rise of Italian Fascism which was implacably opposed to multiculturalism and multilingualism in general, as well as to translation from other languages into Italian even though translational exchange in the opposite direction, from Italian into other languages, was considered desirable.

During the decades which followed, Trieste went through a process of Italianization resulting in a considerable decrease in the number of Slovenes, together with that of other ethnic groups, compared to the number of Italians. However, the surrounding areas which historically were Slovene-speaking and present a natural continuation of the Slovene ethnic territory on the other side of the border, have preserved their ethnic character to a larger degree, a fact that is today reflected in the official bilingual status of the area, although not of the city itself. Nonetheless, communication in Slovene in official settings has recently been on the increase in Trieste, as exemplified by its use at meetings of the Regional Council of Friuli-Venezia Giulia which has its base in the city, and by enhanced interpreting activity. With respect to language policies, this confirms "that translation is largely dependent on them, but that it also constitutes a key determinant of their effectiveness" (Grin 2010: 17). It may be assumed that in Trieste official bilingualism is now gaining ground, slowly becoming institutionalized at least in certain types of formal situations, with greater institutionalization of the Slovene language bringing greater linguistic equality and ultimately conferring on the minority language a higher status (Meylaerts 2011: 62). However, as shown by numerous officially bilingual environments around the world, even the status of official bilingualism cannot put an end to various sorts of hidden or overt conflicts between the two ethnic communities endeavouring either to maintain or subvert the power relations between their languages (see Simon 2012a: 3), which often have significant implications for the necessity, desirability or refusal of translation. So, even if Trieste may be on the long road to becoming a truly bilingual city, it will at the same time remain what Sherry Simon has called a "dual city," referring to urban spaces in which "two historically rooted language communities feel a sense of entitlement and lay claim to the territory of the city" (Simon 2012b: 130): 
One might want to call such cities bilingual, but the term is misleading. Languages that share the same terrain rarely participate in a peaceful and egalitarian conversation: their separate and competing institutions are wary of one another, aggressive in their need for self-protection. Other languages also enter the conversation. (Simon 2012b: 130)

As will be shown in this paper, Trieste certainly qualifies as a dual city, in which enduring stereotypes of the Other's language and culture have in important ways shaped the everyday life of its two main ethnic communities, both of whom have often felt threatened at the prospect of having their physical and symbolic territory occupied by the Other. The concept of "conquest" is indeed a relevant one in the context of bilingual cities in particular and of bilingual territories in general, as underlined by Simon:

Linguistically divided or dual cities have their origins in conquest, when a stronger language group comes to occupy or impinge upon a pre-existent language - which may have itself displaced another before it. Empires are especially effective creators of dual cities: administrative or settler colonies impose an imperial language which carries with it values of power and cultural prestige. (Simon 2012a: 3)

\subsection{Trieste's literary cultures}

In spite of political manipulations and divisions, Slovenes and Italians have managed to live with each other in the city as well as in its surroundings for centuries. Since the second half of the nineteenth century, the two ethnic communities have enjoyed a rich cultural life. Part of that is a remarkable literary output which, with respect to the rest of Italian and Slovene literature, is considered distinct enough - in linguistic terms as well as in terms of the approaches adopted in dealing with individual themes and topics - to constitute two literary subsystems of their own and be referred to as Triestine literature (It. letteratura triestina, Slov. tržaška književnost), now an accepted term both in Italian and in Slovene literary studies, serving as more than merely a geographical label. As pointed out by Angelo Ara and Claudio Magris (1987: 68-69), Italian Triestine literature had long lacked a character of its own, its authors being simply minor figures of Italian literature, until the appearance of writers like Italo Svevo, Umberto Saba, and Scipio Slataper at the end of the nineteenth and in the first decades of the twentieth century. The canonical texts of these writers now bear an imprint of triestinità, whose specific trait is considered to be an analytic approach to the subject matters dealt with. According to Ara and Magris (1987: 73), it was the very lack of a deep-rooted cultural tradition, characteristic of many other Italian literary environments, that at one point made possible the unhindered growth of a new literary culture with a recognizably analytical slant developed through a process of reflection on the crisis of civilization at the turn of the century as perceived by certain Triestine authors, in particular Svevo. It is difficult to assess whether a similar analytic character is also a defining feature of Slovene Triestine literature, which on the whole shows important differences compared to its Italian counterpart. However, within Slovene literature, it undoubtedly constitutes a subsystem of its own since its texts present not only distinctive linguistic features but are often characterized by a breadth of vision akin to cosmopolitanism, rare elsewhere, as well as by a thematization of issues related to the social position of an ethnic minority and its relationship to the dominant culture. 
The city's literary production has been the subject of various studies which have taken into account the multicultural aspects of the reality underpinning Triestine literature (Ara and Magris 1987; Pizzi 2001) and in some cases their relevance for translation (Simon 2012a, 2012b). However, the role of the Slovene element in the city's multilingual and multicultural texture has not yet received due attention since research has so far concentrated chiefly on Triestine literature written in Italian, also taking into account the incomparably smaller number of literary texts in German by authors such as Theodor Däubler, Robert Hamerling, Heinrich von Littrow, and others (see Ara and Magris 1987: 68-70), who spent major parts of their lives in the city or its surrounding area. Within the German literary system, their works are considerably less important compared to the value ascribed to certain texts by Italian Triestine authors in the corpus of Italian literature. Apart from minor German writers whose life and work were in one way or another inseparably linked to the city of Trieste, there is also the figure of Rainer-Maria Rilke whose Duineser Elegien (Duino Elegies) were begun in 1912 when he was a guest at the castle of Duino on the northwestern Triestine riviera. However, no matter how central Rilke's stay may have been for his famous cycle of elegies, his connection to the region remains too weak for his work to be considered as part of Triestine literature.

There is yet another literary giant whose personal and literary biography is linked to Trieste and, in fact, inextricably so: James Joyce, who spent well over a decade in the city. This was for him a particularly formative time and the linguistic (and cultural) hybridity of Trieste may have fundamentally encouraged his explorations of linguistic heterogeneity as an essential element of his mature fiction (Simon 2012a: 61-62; see also McCourt 2009). Notwithstanding the importance of the years Joyce spent in Trieste for his literary development, he too cannot be counted among Triestine authors in a strict sense, since his work is primarily anchored in a different literary tradition and Trieste was but a stop-over, although a long and significant one, on his literary and personal journey.

The situation is, of course, very different for Triestine authors writing in Italian or in Slovene, many of whom spent their entire lives in the city or its immediate surroundings, or remained strongly connected with that environment. Their attachment to the Triestine milieu is often directly reflected in the geographical, historical, and social settings of their textual worlds. In several cases, their works, which display distinctive thematic and linguistic features, are of high literary value and are considered an integral part of the canon of Italian and Slovene literature respectively. It may be worth mentioning that several Italian-speaking authors from Trieste and the area chose to write in dialect, including Virgilio Giotti, active in the first half of the last century, who is recognized as a notable dialect poet at a national level, as well as Lino Carpinteri and Mariano Faraguna, who co-authored a number of humorous prose texts and plays some decades later. However, the most prominent Triestine writers, both Italian and Slovene, did not express themselves primarily in dialect, although their language is often strongly impregnated with features alien to standard Italian and standard Slovene. This hybridity is, to a large extent, the result of the multilingualism of the authors' environment. The classical Italian Triestine prose writers Italo Svevo (1961-1928) and Scipio Slataper (1888-1915), and the poet Umberto Saba (18831957) are particularly well-known and representative. On the Slovene side, the foremost figures of Triestine literature are Vladimir Bartol (1903-1967), whose novel 
Alamut (originally published in 1938) achieved wide popularity in France, Spain, and Italy at the end of the last century, Alojz Rebula (b.1924), who has authored a number of complex texts often dealing with religious and existential questions, and, especially, Boris Pahor (b. 1913), who, over the past decades, has risen to prominence in several European countries like France, Italy and Germany, mainly thanks to the novel Necropolis (orig. Nekropola, 1967) in which his concentration-camp experience is narrated. Ironically, his Italian acclaim only came in 2008 when the text's Italian version (Necropoli) was finally published not by a local but by a Roman publisher (Fazi Editore), with a foreword by Claudio Magris, after the novel had previously appeared in Italian in 1997 and 2005 with very limited impact. ${ }^{5}$ Many of Pahor's other texts also address the question of extreme suffering inflicted by fellow human beings, which is explored through the author's personal Nazi concentration-camp experience. The theme of suffering and humiliation in time of war is complemented by another subject grounded in an equally concrete experience, namely the life of an ethnic minority.

\subsection{Two marginal literatures - yet in different ways}

Given the fact that Italian and Slovene Triestine literatures are tied to the same physical and, to a degree, cultural space, it is surprising that the latter has received only limited attention from researchers. If initially the motivations for not taking the works by Slovene Triestine authors into due account were largely political and social, more recently the relative lack of attention can be explained in large part by the language barrier. The majority of researchers interested in the multilingual and multicultural dimension of Triestine literature and its relevance to translation appear to have no direct (or only very limited) access to literary texts in Slovene, which as a result have been considered at best merely in passing. In fact, language has been an obstacle for a number of scholars, including Katia Pizzi (2013) as well as Angelo Ara and Claudio Magris, whose bonds with the city are particularly strong and whose research work on the identity of Trieste (Ara and Magris 1987) remains a cultural history milestone. While their research does show a high awareness of the Slovene side of the city, it nevertheless fails to provide a more thorough insight into Trieste's (literary) culture, which could only be gained by taking into account Slovene primary sources as well.

However, if the uneven attention researchers have given to the Italian and the Slovene components of Triestine literature respectively is readily explicable, the mutual lack of interest in the Other's cultural output, with important consequences for translation, is more striking. Until recently there has been relatively little translation of Italian Triestine literature into Slovene, and only a few works of Slovene Triestine literature have been translated into Italian or found their way to Italian readers. What is more, the overall volume of Slovene translations of Italian literature is considerable; in fact, Italian literature figures among the literatures which have received a relatively large amount of translational attention (although less than, for example, German, English or French). Likewise, Slovene literature - in spite of representing less than $0.5 \%$ of the total production of translations into Italian - remains one of the Slavic literatures most frequently translated into Italian, exceeded only by Russian literature (Ožbot 2011: 513), although many translated texts are published in 
the border region of Friuli-Venezia Giulia and often do not reach an audience elsewhere in Italy.

The rather low degree of mutual translation of literary works in the Trieste area is particularly intriguing when one considers that for centuries, especially within its largely bilingual Slovene community, translation in its various forms has been very important in day-to-day communication, on an individual as well as on a societal level. This is exemplified, among other things, by the linguistic hybridity of Slovene Triestine literature (for example, works by Boris Pahor), which often include translated material in the form of lexical and syntactic calques along with various other kinds of interlinguistic transfer that are, ultimately, a result of translation (Ožbot 2009). Similar phenomena were observed in the works of Italian Triestine writers, notably Italo Svevo (see Simon 2012a: 56-58), and, more generally, in the works of authors from other multicultural environments, for instance Franz Kafka, whose life in Prague, like Svevo's in Trieste, was on the periphery of the Austro-Hungarian Empire. Both cities, one for a long time predominantly German-speaking and the other, in the past as well as now, Italian-speaking, were surrounded by territories that were linguistically very different from them, the former Czech- and the latter Slovenespeaking. The literary language of these writers displays uncertainties and exploits their expressive potential with the help of the contact codes present in the environments where they (have) lived. Kafka's German, Svevo's Italian or Pahor's Slovene are all products of linguistically hybrid contexts from which material is drawn and used in idiosyncratic ways. Language use by these authors contrasts rather starkly with how the same languages are employed in literary and non-literary texts produced in more central and linguistically less hybrid areas. Literatures which are considered geographically marginal can also be linguistically marginal. As such, they may qualify as minor - to use a concept developed by Gilles Deleuze and Félix Guattari in their study of Franz Kafka. In fact, one of the fundamental traits of minor literatures is a deterritorialization of language (déterritorialisation de la langue, Deleuze and Guattari 1975: 29-30) brought about by the separation between standard linguistic use and the more unconventional intensive use of language characteristic of a minor literature. That said, whereas Kafka's German was anchored in Prague, a linguistic island surrounded by a much larger Czech-speaking area and thus physically separated from "mainland" German, the situation is different in the case of Triestine literature, both Italian and Slovene. Their separation from the rest of Italian and Slovene literatures is a product not of physical isolation but rather of their being grounded in a multilingual environment.

The relatively unusual, unidiomatic use of Italian in Italian Triestine literature stems not only from the city's character as a contact zone shared by different languages and cultures, whose effects upon an individual's linguistic use may be further increased through intense linguistic socialization in a second language, as in the case of Italo Svevo, in whose education German figured prominently. There is yet another reason for the uneasiness certain Triestine Italian writers feel with respect to standard Italian. Triestino, the local dialect, now a variety of the Veneto dialects - one of which is also Venetian, used in the city of Venice - whereas its former variety, alive until the first decades of the nineteenth century and known as Tergestino, exhibited more Friulian traits (see Marcato 2011), has played a prominent role, in Svevo's time as well as today, across all social and generational strata. The double strangeness 
of traditional literary Italian to Triestine writers derives, then, from the different sorts of bilingualism (or often, indeed, diglossia) characterizing the city: on the one hand, from interactions between Italian and other languages, such as Slovene or, to a lesser extent, German, and, on the other hand, from the presence of an internal Italo-Romance diglossia, involving Triestino as a widely used local idiom, especially in spoken and less formal communication, and standard Italian, reserved chiefly for written and strictly formal communication. By contrast to Italian Triestine literature, the dichotomy between dialect and standard language is of less consequence for Slovene Triestine authors, but there are nonetheless other important shared traits: these texts are produced in a common multilingual and multicultural space and exhibit a wide range of linguistic contact phenomena, some of which are typical of the general Slovene or Italian linguistic use in the city, whereas others may be restricted to individual writers' idiolects.

\section{On parallel (non)-translation}

As noted above, although works of Italian and Slovene Triestine literature bear witness to the area's heavily multilingual and multicultural character, when it comes to reciprocal literary translation the output is rather modest, and the reception of translated works often even more so. It appears that despite being contiguous or even partially overlapping, the two literary subsystems have led largely separate lives. The mutual lack of interest, which has sometimes gone as far as total indifference, is perhaps all the more surprising in a city where awareness of the importance of translation has been rather high. In fact, for decades the University of Trieste has been home to a well-known school for the training of translators and interpreters, which until the late 1980s was the only one of its kind in Italy and whose founding in a culturally and linguistically mixed border area was not a matter of pure chance.

A few facts may suffice to illustrate the relative rareness of translated literary texts. The first Slovene translation of Umberto Saba's poems in book form appeared in 2008, over fifty years after the author's death in 1957, and Una vita (1892), the earliest of Italo Svevo's three major novels, has not yet been translated, whereas his other two novels La coscienza di Zeno (1923) and Senilità (1898) appeared in Slovene in 1961 and in 2001 respectively. In the case of Slovene Triestine literature, Boris Pahor's texts had hardly been translated into Italian before he became an internationally acclaimed writer towards the end of the 1990s; they had to wait a decade before attracting the wider attention of Italian literary critics and readers. Translations of his works into other languages, especially into French and German, not to mention Italian, contributed to finally awakening an interest in his works among Triestine Italian readers and to him earning recognition as a prominent author. He was made an honorary citizen of Trieste in 2013. Works by other Slovene Triestine authors, when translated at all, have usually been published by small houses with limited distribution (some of whom are in fact Slovene and publish books in Italian sporadically); they therefore have little chance of being read by an interested Italianspeaking audience, no matter how small. 


\subsection{Italian-Slovene translational relations in Trieste}

This relative lack of interest in mutual translation calls for analysis as an indicator of a more general disinterest in the Other. The question to be asked at this point is the following: what could possibly be the reasons for the rather limited literary and in particular translational exchange between the two communities, which - it seems - have been living parallel lives instead of actively crossing each other's paths? Necessarily, a variety of issues are at play that involve a complex interaction of political, social, ideological, cultural, literary, and linguistic aspects to be examined from a historical and contemporary perspective. A possible starting point may be the observation that, especially in the past, the relationship between the two ethnic communities has been strongly asymmetrical, with the Slovene community occupying the lower end of the socio-cultural demographics of the city and, therefore, in many respects a subordinate position in relation to the Italian community. In spite of sharing a territory for centuries and jointly shaping the life of their city, the two communities and the two peoples have had very different histories.

In light of this fact, it is not surprising that Italians and Slovenes in Trieste have led largely separate lives, often ignoring each other. For both communities, the "Other remains within constant earshot" (Simon 2012a: 7), but is often perceived as an intruder in the territory, the perception of which tends to vary. A study conducted in the mid-90s aptly illustrates how the common space is perceived differently by members of the two ethnic communities (Sbisà and Vascotto 2007). High-school pupils of different age groups, some from Italian and some from Slovene schools in the area, were asked to try to make a detailed presentation of the province of Trieste for someone who did not know it. As the results show, some meaningful differences can be detected from their descriptions. These differences concern both the natural characteristics of the territory as well as an awareness (or lack of it) of the other ethnic community sharing the same physical space. For instance, the sea figures more prominently in the texts produced by the Italian pupils, while the Karst hinterland has a greater role in those written by pupils from Slovene schools. As to the presence of the Other, in some cases an awareness is totally absent, especially in Italian pupils. Perceiving the territory as ethnically homogeneous, $97.8 \%$ of pupils do not find it relevant to talk about their ethnic identity, whereas with Slovene pupils this is less often the case: $35.5 \%$ of them explicitly mention their ethnic identity, which is consistent with "the tendency to self-awareness that is characteristic of minorities" (Sbisà and Vascotto 2007: 163). The study gives further proof that the lives of the Italian and the Slovene communities proceed largely in parallel:

[...] the image of the other hardly plays any role in the way majority members represent the territory and even among minority members, the affirmation of one's own identity is not always accompanied by manifestations of awareness of the presence of a diverse majority. Throughout the corpus, perhaps with the exception of two Slovene texts, whenever the distinction between the Italian majority and Slovene minority is represented, it is conceived of as neat, and those hybrid or complex identities, that contact cannot fail to produce, are disregarded. (Sbisà and Vascotto 2007: 166)

It should therefore not come across as surprising that parallel activities rather than interaction have also characterized to a considerable extent the literary and translational relations between the two communities. 


\subsubsection{Politics, society, and - language}

As observed by the historian Angelo Ara (2009: 308), the division between the city, which is predominantly Italian-speaking, and the country, which is prevalently Slovene (and Croatian farther to the south), has not only provoked continuous social and ethnic tensions between the two societies, an urban and a rural one, but has also been the root of strong territorial claims over the region as a whole by Italians and Slovenes, whereas, historically speaking, each of the two ethnic groups has dominated only part of the region. It appears, though, that antagonisms started to be truly felt only in the mid-nineteenth century with the spread of the national revival movement, which was particularly strong in the Austro-Hungarian Empire, when it became clear that the multinational state could no longer offer a satisfactory model of co-existence to its various socio-cultural communities, who found their inferior position with respect to the dominant German-speaking community increasingly unbearable. As Ara notes (2009: 304), the development of national consciousness in the subordinate peoples led to an increase in national conflicts between different ethnic groups, which could be particularly intense in multilingual and multinational border regions at the margins of the empire, one of which was the area around Trieste. The latter's problems must therefore be considered national and linguistic, affecting the much larger area in which Italians lived together with Slavic and German populations.

Although migration towards the urban area of Trieste had been strong from the proclamation of the free harbour at the beginning of the eighteenth century until the Spring of Nations (1848), national awareness had not matured enough to become an agent of conflict between the two communities. Newcomers to the city - most of whom were Slovene, but there were also immigrants of various other ethnic backgrounds - became largely assimilated into the urban Italian-speaking majority. Moving upward on the social ladder often implied a shift of language and, in the end, a change of ethnic identity (Ara 2009: 305). Also, throughout the eighteenth century, linguistic identity was linked to social status rather than being a pivotal point of national awareness (Remec 2012: 215).

As national consciousness developed, ethnic belonging became an active agent in identity construction, which was found disturbing especially in certain Italianspeaking circles, whose position as the socially dominant group began to erode. Also, the sheer number of immigrants to the city increased to such a degree that they could simply not be absorbed by the Italians (Ara 2009: 305). This suggests that economic circumstances and rapid urbanization provoked an intensification of interethnic conflicts (Ara 2009: 311). Moreover, to mitigate its subjects' mistrust of the state, in 1867 the Habsburg Monarchy passed a law, as part of the December Constitution, whereby, according to Article 19, the peoples of the Austrian part of the Empire had the right to assert their own national and linguistic rights and, as a consequence, use their languages in education, administration, and public life in general (Verginella 2002: 456). In 1883, during Taaffe's rule as Austrian prime minister, the Imperial Council granted Italian, Slovene, and Croatian equal status as languages of the law courts in the areas inhabited by the three ethnic groups (Černigoj 2007: 70). As a result, Trieste was gripped by tension between "an imperial tongue and a national language" (Simon 2012a: 58) and, at the same time, by ever-louder claims for national and linguistic rights made by the Slovene and, more generally, the Slavic population. 
National issues came to dominate virtually every aspect of life, and battles for language rights, a symptom of complex and deep-seated national problems, were played out. Considering that language struggles imply the recognition of the Other's linguistic identity through bilingualism and necessarily involve (often painful) processes of translation, one has to agree with Simon's assertion in relation to the cities of Mitteleuropa that "translation in the twentieth century must first and foremost be identified as a form of violence and coercion" (Simon 2012b: 133). As far as Trieste is concerned, this is how language wars were perceived by different segments of its population at different times.

Among the most notorious and perhaps best-documented language struggles in the area in and around Trieste were those over bi- or multilingual public signs on court houses in the coastal town of Piran/Pirano (Černigoj 2007) and bi- or multilingual place-name signs at railway stations on the line between Trieste and the Istrian resort Poreč/Parenzo (Černigoj 2010). The opening of Slovene language schools was also considered extremely problematic by a large part of the Italian population, as was the case in the Rojan/Roiano suburb of Trieste (Ara 2009: 311; see also Ara and Magris 1987: 65). The concession of language rights to Slovenes (and Croats) regularly triggered demonstrations within the Italian population, for whom the questioning of the established language hierarchy was perceived as a threat to its position, which was vulnerable to an extent since, in Austria-Hungary, Triestine Italians too were a minority, in spite of living in a city where they were numerically and culturally dominant. The central Viennese government, however, seemed rather favourable to making Slovene an official language (Amtssprache) - possibly as a sign of recognition of an ethnic group that was considered more loyal to the Emperor than the Italians living in the Empire and as a means of restraining burgeoning Italian national awareness. In actual fact, the Italians perceived themselves as the legitimate owners of the territory not just because of their numerical preponderance and cultural supremacy, but also because they believed themselves to be the direct heirs of Roman civilization, which predated the settlements of the Slavs in the area by several centuries. From their point of view, then, the Slavic national awakening was illegitimate in that it threatened long-established relations of power and, in particular, the Italians' status as the "indigenous" people of the territory (Verginella 2002: 459). The zenith of anti-Slavic nationalism was reached in the Fascist period (1922-1943), when the use of Slovene was officially prohibited.

Yet it would be unjust to consider a negative attitude towards Slovenes as characteristic of the entire Italian-speaking population of the city. In addition to the Triestine working class, for whom mutual worker solidarity was placed above ethnic identity, there were also several other individuals and groups for whom peaceful coexistence between Italians and Slovenes (and Slavs in general) was essential and who sought to find ways of achieving it. Among them one can find socialists like Angelo Vivante, democrats like Fabio Cusin, some Catholics as well as some irredentists, that is, anti-Austrian Italian patriots like the writer Scipio Slataper (Ara 2009: 311) and his circle, who were aware that the identity of the area had been shaped by the different ethnic groups living in it (Ara 2009: 312). 


\subsubsection{Culture, literature, and - language}

The asymmetrical relationship between Slovenes and Italians evident in the political and social spheres may have also been present in the cultural sphere and, in particular, in the literary sphere, where Italians had for centuries been one of the leading nations with a highly developed literary tradition since as early as the fourteenth century and a full-fledged literary language. The earliest Slovene texts, by contrast, date back to the early eleventh century, but for some eight centuries after that the textual production in Slovene was relatively meagre, with the exception of some more prolific periods such as the Reformation which saw, among other things, the first Slovene translation of the Bible in 1584, followed by the Baroque period, when some fine examples of homiletic literature were produced, and the Enlightenment, with a significant output of secular plays. But as a whole, Slovene literature did not begin to flourish until the first decades of the nineteenth century and the Spring of Nations in 1848. As to be expected, language development proceeded in parallel with literary development, although it took a long time before Slovene became accepted as a suitable medium for all kinds of literary and non-literary communication. It is also important to take into consideration the socio-political status of Slovene: until 1918 its public use was very limited and it only acquired a wide functional scope after the Second World War, at the time of socialist Yugoslavia and especially after Slovenia's independence in 1991. Obviously, the situation with Italian was very different: although in many areas of non-literary language use the Latin tradition was strong and although Italy was united only in 1861, Italian had for centuries been used in a great variety of situations. In spite of the dominance of dialects in day-to-day oral communication, it had reached a state of maturity much earlier than Slovene.

Given the different dynamics of literary and linguistic development in the two cultures, it is not surprising that the Slovene community, which in addition was associated much more with rural than urban life and therefore had a socially subordinate position, was not considered of much interest to the Italian part of the city's population. The political and social conditioning of the reception (or lack of it) of Slovene literature abroad was remarked upon by the Triestine intellectual Angelo Vivante, author of a highly unorthodox treatise on the development of Italian nationalism in Trieste and the surrounding region, Irredentismo adriatico (1912), who attributed the limited reception of Slovene literature outside its native territory to external political and social circumstances (Vivante 1912/1984: 158) rather than to its intrinsic nature.

The political situation between the end of the First World War and the fall of socialism in the late 1980s only strengthened the negative attitude towards the Slovene Other and their culture, thereby worsening the relations between the two ethnic communities. Initially, this happened partly because of the militantly nationalist Fascist ideology, among whose prime targets were the Slavs, but also because Trieste and its surroundings were for a long time part of a disputed territory, which after the Second World War was claimed by both Italy and Yugoslavia. However, the post-war ideological circumstances made the situation worse: after 1945, Italy and Yugoslavia formed different ideological alliances. Italy developed into an important Western power, whereas Yugoslavia, although non-aligned, practised a softer version of communism. The antagonism between the two ideologies was felt in a particularly 
strong way in Trieste where the new communist state was often viewed with great suspicion. The Slovene minority, in its turn, despite being in ideological terms internally divided, was often automatically associated with the communist neighbour on Italy's eastern border. Needless to say, such a strained relationship in no way contributed to the promotion of a productive mutual interest between the two communities, their cultures, and their literatures.

The situation changed considerably after the fall of socialism, with Slovene independence, the country's entry in the European Union (EU) and Slovene becoming one of the official languages of the EU, which all enhanced the language's perceived status and increased the interest in Slovene literature (see Meylaerts 2009: 98). Asymmetries, which are characteristic of multilingual societies, continue to persist and are certainly unavoidable, but it appears that the gain in political power has conferred upon the community some of the linguistic, literary, and cultural legitimacy which it previously lacked: Slovene literature is now being translated into Italian with more success than in the past and the Italian-speaking population of the city is increasingly interested in learning the Other's language. There are many other signs pointing to a change in attitude, which could hardly have been imagined twenty or thirty years ago. For instance, the city's daily newspaper Il piccolo has been dedicating considerable attention to issues related to Slovenes and their culture. Likewise, several of Trieste's Italian bookshops display in their shop windows and on their shelves books about Slovenia and Slovene culture, including translations of Triestine Slovene literary texts into Italian. ${ }^{6}$ The current situation clearly demonstrates the fundamental link between multilingualism and translation. "The question of which language(s) can/cannot/must be used necessarily implies: which one(s) can/cannot/ must be translated from or into, by whom, in what way, in which geo-temporal, institutional framework etc." (Meylaerts 2006: 2)

Interestingly, the development of a new perspective on the Slovene Other can also be observed in literary texts by Italian authors in which various attitudes towards Slovenes are expressed. Traditionally, such attitudes tended to be negative (though not without exception), especially in the period immediately following the Second World War, when the brief but intense Yugoslav occupation of the city left a deep mark, as can be seen in, for example, Pier Antonio Quarantotti Gambini's anti-Slavic writing. Later, however, feelings of denial and, at best, indifference were gradually transformed into an interest in and openness towards the Other, as seen, for example, in novels by Fulvio Tomizza, Tullio Kezich, Renato Ferrari, and Carolus Cergoly (Barut Polman 2012).

The perception of Slovenes as a coarse, uncivilized, and even aggressive people did not help generate interest in their literature and culture. This had direct consequences for translation, since a negative attitude towards a community and its language usually implies a tendency to refuse translations from that language. A shift in perspective became apparent in the early 1990s, when political, social, and language-policy started to change. The asymmetries between the two ethnic groups began to diminish, and Slovene culture started to gain recognition in the areas of language and translation, with Slovene being learned by Italian Triestines, some Italian children attending Slovene schools, and translational exchange seeing an increase. These seem to be significant signs which point to the emergence of a new bilingual awareness in the city. ${ }^{7}$ 


\subsection{Reduced asymmetries and new perspectives}

The new situation of reduced asymmetries has made possible a breakthrough for Slovene translated literature. By recognizing that, in Trieste, the Italian and Slovene communities, despite their many differences, have for a long time shared and shaped an important reality which is the urban territory itself, the dominant Italian culture has begun to accept the presence of the Other and make space for the city's Slovene culture. Rather than perpetuating the clash between a prestigious central culture, on the one hand, and a less established peripheral culture, on the other hand, the two communities have begun to build a mutual relationship revolving around a common core. This explains the success of various cultural projects recently carried out, first and foremost the highly positive reception of the Italian translations of Boris Pahor's texts.

As has been shown by studies on the reception of translated texts, especially when they belong to peripheral literatures and are "exported" into central cultures, various text-internal and text-external factors are at play, such as the quality of the translations, their distribution on the book market, and promotional events accompanying the publication (see Ožbot 2011). However, apart from all that, the necessary - although insufficient - condition which may be central to the successful reception of a translation is its communicative potential for the target audience and, ultimately, the latter's willingness to acknowledge it. In other words, without sufficient common ground between the translated text and its readers, productive communication cannot take place. It seems that Triestine Slovene literature has only been able to offer such communicative potential to Italian Triestine readers since the political, social, and linguistic situation has become more balanced, which has allowed the city's other community to be seen less as an opponent and more as a neighbour, who has something to offer in terms of its culture and historical experience. Boris Pahor's works have always dealt with universal questions that transcend the immediate historical circumstances against which they are explored, which is, after all, the reason why they have been well received by such cultures as the French and German-speaking. However, success in their home environment only came about after potential readers became receptive to his texts, recognizing in them enough common ground. As already mentioned, the author's international success was undoubtedly instrumental in the promotion of his works at home, but a new relationship between the Italian and the Slovene communities of the city has also played a fundamental role in the reception of the translations.

On the Slovene side, the literature of Italian Triestine authors is currently being translated to a greater extent than ever before: over the past five years translations of Umberto Saba's collection of poems as well as of his novel Ernesto have been published and Slovene versions of some contemporary authors' texts, such as wellestablished Claudio Magris and young and innovative Mauro Covacich, have also been produced. However, the reasons why this did not happen earlier and on a larger scale are probably more of a practical than of a political nature. Within the Slovene Triestine community itself, there has been no immediate need for translation since virtually all its members are bilingual, as is often the case in asymmetrically bilingual societies, where the "subordinate" group is more likely to be bilingual than the "dominant" one. As for the Slovene translational culture as a whole, its relative lack 
of interest in Italian Triestine literature compared to many other Italian literary texts was conditioned mainly by the personal preferences of the available literary translators (already not numerous), who chose to work on classical texts (for example, Dante, Boccaccio, Petrarca), modernist poetry (for example, Montale, Quasimodo, Ungaretti), contemporary post-World War II novels (for example, Moravia, Sciascia, Camilleri), and plays (for example, Goldoni, Pirandello, De Filippo) rather than on texts of Triestine literature, with the exception of some authors whose works explicitly deal with themes directly related to Slovenes and their culture, in particular when the former express a positive attitude towards the latter. This is the case of Scipio Slataper's Mio Carso (published in 1912; translated in 1988), which stresses that constructive dialogue between the two ethnic groups is an indispensable basis for their future co-existence, as well as of several novels by the Istrian-born Triestine author Fulvio Tomizza, most notably perhaps his Glisposi di via Rossetti: tragedia di una minoranza (published in 1986; translated in 1987), which deals with the death of a politically committed Slovene couple who were murdered in their Trieste flat in the middle of the Second World War by a perpetrator who continues to remain unidentified to this day.

In terms of publishing activity, approximately 40 books by Slovene Triestine authors in Italian translation have been published in the city since the early 1970s. A few came out before the mid-1980s, when the social and political climate began to change, and over one half have been published since 2000. The majority of these works were issued by Slovene publishers based in Trieste (mainly ZTT and Mladika), although various Italian Triestine publishing houses (for example, Ramo d'oro, Comunicarte, Antony, Hammerle) also produced some of the editions. Several Slovene Triestine authors have had their texts published by other Italian publishing houses, some of which are of national importance (Rizzoli, Fazi), whereas others are (or were) much smaller or specialized. The latter include the publisher Nicolodi and its successor Zandonai, both based in Rovereto and interested in the production of Central European authors. Alojz Rebula, whose writing has a religious dimension, has had some of the translations of his texts published by the well-known Catholic publisher San Paolo. In addition to literary works in Italian translation, both Slovene and Italian Triestine publishers have produced translations of works by a few Slovene authors from central Slovenia, who are not part of the Slovene community in Italy, as well as some non-literary works originally written in Slovene concerning mainly historical and cultural topics.

Turning to translation in the opposite direction, a similar number of texts of Italian Triestine literature have been translated into Slovene, the first one appearing in 1961 (Svevo's La coscienza di Zeno), followed, again, by several in the 1970s, 1980s, and 1990s, with the vast majority published after 2000. Approximately $60 \%$ of the translations were produced by publishers from Slovenia and a few of them by a Slovene-owned publishing house from Austrian Carinthia (where there is a Slovene national minority); the rest were released by the two principal Slovene publishers in Trieste. The fact that these publishers include in their catalogue Italian texts in Slovene translation, which are not primarily intended for the city's strongly bilingual Slovene community, can be explained by the nature of the Slovene book market that functions to a degree like a unitary one. This is reflected, for instance, in the Slovene publishers from Italy (as well as Austria) being represented at the annual national 
book fair, along with publishers from mainland Slovenia. However, it is not only the Slovene publishing space that is increasingly being perceived as unitary, at least in terms of the accessibility of books to Slovene readers from Slovenia and from across the border. A sense of belonging to one and the same place (physical or virtual), which is a condition for community formation, can also be detected among modern Triestine authors. In 2000, the anthology Poeti triestini contemporanei was published by the Italian Triestine publisher Lint. It includes both Italian and Slovene poets, along with other authors who live in the city, but are not members of either of the two main ethnic groups.

\section{A closing thought}

By way of conclusion, I would like to point out that Trieste's Slovene and Italian communities offer another example of the typical attitude towards translation displayed in many bilingual situations: lack of translation tends to imply self-centredness and disrespect for the Other, as well as "resistance to change" (Koster 2010: 44), whereas the presence of translation is a sign of acknowledgement of the Other. If the present trend continues, Trieste will become a more bilingual as well as a more translationminded city.

\section{NOTES}

1. Some recent case studies dealing with issues of non-translation or limited translation activity are offered in Koster (2010), Pięta (2011) and Tahir Gürçağlar (2013), although they pertain to more geographically distant cultures.

2. The presence of Friulians, a Romance-speaking people inhabiting the easternmost borders of present-day Italy and the Romance world in general, was natural, given that the area they settled in lies only a few dozen kilometres to the north-east of Trieste.

3. According to the 1910 census, there were approximately 60,000 Slovenes living in Trieste, whereas the number of Italians was around 140,000. The survey, however, was not without problems. The way in which the questionnaire was designed was disadvantageous to non-dominant ethnic groups. In as much as ethnicity was taken to be based on language, the results obtained deviated from the actual state of affairs, for the subjects were asked to identify their language of ordinary use (Umgangssprache), which was not necessarily their native language or the language they would identify with, but, for instance, the language they would use at work or in the most general dayto-day social interaction.

4. At the beginning of the century, the idea of establishing a Slovene university in Trieste was not totally new. Antagonisms between Italians and Slovenes notwithstanding, there were some Italian intellectuals who viewed the cooperation between the two ethnic groups with a favourable eye. One of them was Nicolò De Rin, a Triestine lawyer of anti-Austrian orientation, who suggested to a communal board that it should ask the Austrian government permission to found a School of Law in Trieste that would be Italian-speaking and also include a Slovene-speaking chair (Vivante 1912/1984: 144).

5. All the Italian editions have used the translation by Ezio Martin, although with several modifications with respect to the version published in 1997.

6. Recently, an anthology edited by Marija Pirjevec and designed for Italian-speaking readers interested in the city's Slovene culture, especially in its literature, has come out under the telling title L'altra anima di Trieste ([Trieste's Other Soul]; Trieste: Mladika, 2009).

7. As François Grin (2010: 16) put it: "[...] people will use a variety of languages (instead of only one) if three conditions are present. These three conditions are: the capacity to use these languages, opportunities to use them, and the desire to do so. Typically, therefore, language policies will try to influence capacity, opportunity and desire - in varying proportions depending on context and objectives. [...] Translation itself is a key conduit for language policy, because it reinforces capacity, opportunity and desire." 


\section{REFERENCES}

Ara, Angelo (2009): Fra nazione e impero: Trieste, gli Asburgo, la Mitteleuropa. Milano: Garzanti. Ara, Angelo and Magris, Claudio (1987): Trieste: Un'identità di frontiera. Torino: Einaudi.

Barut Polman, Klavdija (2012): Podoba Slovencev v italijanski književnosti [The Image of Slovenes in Italian Literature]. Unpublished MA thesis. Ljubljana: University of Ljubljana.

Cattaruzza, Marina (1997): Slowenen und Italiener in Triest: 1850-1914. In: Andreas MoriTSCH and Harald Krahwinkler, eds. Alpen-Adria-Städte im nationalen Differenzierungsprozeß. Klagenfurt/Laibach/Wien: Hermagoras, 199-256.

ČernigoJ, Meta (2007): Boj za dvojezične napise v Istri v letu 1894 [The Battle for Bilingual Signposts in Istria in 1894]. Zgodovina za vse: vse za zgodovino [History for all: all for history]. 14(2):69-88.

ČernigoJ, Meta (2010): “Očjo al treno”: zapleti z dvojezičnostjo ob železniški progi Trst-Poreč in druga odprta narodna vprašanja v Istri na prelomu 19. v 20. stoletje [“Očjo al treno”: bilingualism-related complications along the train line Trieste-Poreč and other open national questions in Istria at the turn of the $20^{\text {th }}$ century]. Zgodovina za vse: vse za zgodovino [History for all: all for history]. 17(2):45-66.

Deleuze, Gilles and Guattari, Félix (1975): Kafka: Pour une littérature mineure. Paris: Les Éditions de Minuit.

Grdina, Igor (2003): Slovenci med tradicijo in perspektivo: politični mozaik 1860-1918 [The Slovenes between Tradition and Future]. Ljubljana: Študentska založba [University Press].

GrIn, François (2010): Translation and the Dynamics of Multilingualism. Cahier de recherche ÉLF. 3. Observatoire économie langues formation, Université de Genève. Visited on 3 July 2013, <http://www.unige.ch/traduction-interpretation/recherches/groupes/elf/documents/ elfwp3.pdf $>$.

Koster, Cees (2010): Non-Translation as an Event. The Reception in the Netherlands of John Dos Passos in the 1930s. In: Ton NaAijkens, ed. Event or Incident. On the Role of Translations in the Dynamics of Cultural Exchange. Bern: Peter Lang, 29-46.

LANE-Mercier, Gillian (2011): Éléments pour un nouveau paradigme des rapports de contiguité socioculturelle et disciplinaire. L'exemple du Canada et du Québec. In: Francis Mus and Karen Vandemeulebroucke, eds. La traduction dans les cultures plurilingues. Arras: Artois Presses Université, 161-172.

Marcato, Carla (2011): Plurilinguismo tra realtà e letteratura a Trieste. In: Dario Brancato and Marisa Ruccolo, eds. La terra di Babele: Saggi sul plurilinguismo nella cultura italiana. New York/Ottawa: Legas, 99-110.

McCourt, John (2009): Trieste. In: John McCourT, ed. James Joyce in Context. Cambridge: Cambridge University Press, 228-238.

Meylaerts, Reine (2006): Heterolingualism in/and translation: How legitimate are the Other and his/her language? An introduction. Target. 18(1):1-15.

Meylaerts, Reine (2009): Les relations littéraires au-delà des oppositions binaires: national et international, traduit et non traduit. TTR. 22(2):93-117.

Meylaerts, Reine (2011): Intercultural mediators in multilingual culture: blessing or curse? In: Francis Mus and Karen Vandemeulebroucke, eds. La traduction dans les cultures plurilingues. Arras: Artois Presses Université, 61-72.

Оžвот, Martina (2009): Sloveno e italiano in contatto: qualche osservazione sugli scambi linguistici in una zona bilingue. In: Carlo Consani, Paola Desideri, Francesca Guazzelli et al., eds. Alloglossie e comunità alloglotte nell'Italia contemporanea: Teorie, applicazioni e descrizioni, prospettive. Roma: Bulzoni, 39-52.

Оžвот, Martina (2011): Dwarfs in Giants' Lands: Some Observations on Translating Minor Literatures into High-Impact Cultures - The Case of Slovene Literature in Italy. Meta. 56(3):511-525.

Pį̨TA, Hanna (2011): (Non)translation of Polish literature during the Portuguese first republic. IberoSlavica. 2:99-111. 
Pizzi, Katia (2001): A City in Search of an Author: The Literary Identity of Trieste. London/New York: Sheffield Academic Press.

Pizzi, Katia (2013): Triestine Literature between Slovenia and Italy: A Case of Missed Transculturalism? Primerjalna književnost [Comparative Literature]. 36(1):145-155.

Remec, Meta (2012): "Viva!" ali “Živijo!"?: Slovensko in italijansko časopisje o mednacionalnih konfliktih v Istri v letih 1896 in 1897 ["Viva!" or “Živijo!"? The Positions of the Slovene and the Italian Press on the Interethnic Conflicts in Istria in the Years 1896 and 1897:]. Acta Histriae. 20(1-2):213-232.

Sbisì, Marina and Vascotto, Patrizia (2007): How to conceive of the other's point of view: Considerations from a Case Study in Trieste. In: Sharon Millar and John Wilson, eds. The Discourse of Europe: Talk and text in everyday life. Amsterdam/Philadelphia: John Benjamins, 153-171.

Simon, Sherry (2012a): Cities in Translation: Intersections of Language and Memory. London/ New York: Routledge.

Simon, Sherry (2012b): The City in Translation: Urban cultures of central Europe. Target. 24(1):126-140.

TAhir GürÇAĞLar, Şehnaz (2013): Does the Drina Flow? Cultural indifference and Slovene/ Yugoslav literature in Turkish. Across. 14(2):183-198.

TumA, Henrik (1937/1997): Iz mojega življenja: spomini, misli, izpovedi [From My Life: Memoirs, Thoughts, Confessions]. Ljubljana: Tuma.

Verginella, Marta (2002): Govorica nasilja v slovensko-italijanskem nacionalnem konfliktu [The Language of Violence in the Slovene-Italian National Conflict]. Acta Histriae. 10(2):455-464.

Vivante, Angelo (1912/1984): Irredentismo adriatico. Trieste: Edizioni Italo Svevo.

Wolf, Michaela (2011): The Invention of a "Habsburg Culture": Multilingualism and cultural translation - two sides of the same coin? In: Francis Mus and Karen Vandemeulebroucke, eds. La traduction dans les cultures plurilingues. Arras: Artois Presses Université, 109-121. 